\title{
Article
}

\section{Impact of Retail Strategy, Location and Type of Business on Sales: A Case Study of Peace \& Love Festival Borlänge}

Shujaat, Sobia, Tahir, Iram and Tahir, Owais

Available at http://clok.uclan.ac.uk/38834/

Shujaat, Sobia, Tahir, Iram and Tahir, Owais (2021) Impact of Retail Strategy, Location and Type of Business on Sales: A Case Study of Peace \& Love Festival Borlänge. NUST Business Review, 3 . pp. 28-37.

It is advisable to refer to the publisher's version if you intend to cite from the work. 10.37435/NBR-20-0017

For more information about UCLan's research in this area go to http://www.uclan.ac.uk/researchgroups/ and search for < name of research Group>.

For information about Research generally at UCLan please go to http://www.uclan.ac.uk/research/

All outputs in CLoK are protected by Intellectual Property Rights law, including Copyright law. Copyright, IPR and Moral Rights for the works on this site are retained by the individual authors and/or other copyright owners. Terms and conditions for use of this material are defined in the policies page.

\section{CLoK}

Central Lancashire online Knowledge www.clok.uclan.ac.uk

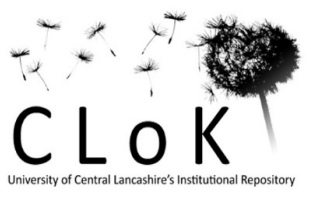




\section{NUST Business Review}

\section{Impact of Retail Strategy, Location and Type of Business on Sales: A Case Study of Peace \& Love Festival Borlänge}

\section{Page 28}

Received: 04 Feb 2021 Revised: 08 Apr 2021 Accepted: 13 July 2021

\section{NBR}

NUST Business Review (C) NUST Business School NBR21020401

Vol. 03 (01)

06,2021

pp. 28-37

DOI:

This is an open access article under the CC BY license

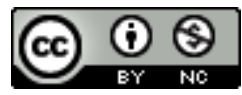

\section{Sobia Shujaat}

Bahria University, Islamabad, Pakistan

*Dr. Iram Tahir

School of Business and Enterprise, University of Central Lancashire, Preston, UK

\section{Owais Tahir}

Department of Management Sciences, SZABIST University, Islamabad, Pakistan

\begin{abstract}
Purpose - This study primarily examines how local retail businesses strategically take advantage of an event like the Peace and Love Festival. The financial effects of the event on these businesses were studied with a focus on whether sales increase or decrease during the Festival. The influence of three important factors was examined; business strategy, location of business and type of business on local businesses' sales during festivals. The study assessed the impact of specific location and the effect of these festivals on different types of businesses. It uncovers the influence of such events on businesses, particularly on their sales. Overall, such festivals have positive financial effects on all local business, except a few, which are further explored in the study.
\end{abstract}

Methodology- The study adopts a qualitative research method in order to obtain a deeper knowledge of how local businesses take advantage of events and festivals. Primary data has been gathered by interviewing local businesses and respondents from Peace \& Love Festival. In total, 22 retailers were approached and interviewed. Non-probability, purposive sampling was used for the research in determining the sample population. Semi-structured, face-to-face interviews were conducted with respondents. The collected data was documented and analysed using interpretivist paradigm and content analysis.

Findings- The results indicate that various types of businesses experience different sales effects during such festivals. Location of retail outlets and their effective strategies influence sales. Findings also show that hotels, fast food restaurants, and beverage sectors show higher sales as compared to other sectors. The retail stores showed slight increase in sales, but electronics/appliances stores experienced almost no change, and some even showed negative sales.

Practical Implication- Businesses can take maximum advantages of such events and enhance their revenue by adopting different strategies. Governments can take advantage of such studies, and promote festivals as they have influential power on attracting large number of visitors towards the host destination.

Keywords: Events/Festivals, local businesses, Retail, Tourism, Marketing Strategies, Peace \& Love Festival, Borlänge.

Paper type: Research Paper 


\section{Introduction}

Tourism is a rapidly growing industry, and has a far-reaching environmental and socio-cultural impact across the globe. In 2010, approximately 940 million people were recorded as arriving in a country from abroad because of tourism, which is worth US $\$ 919$ billion, making it one of the world's biggest industries (World Tourism Organization, 2009). This industry is considered as a basic sector in terms of

NBR

3,1

Page 29 economic significance for any country, and results in creation of job opportunities and promotion of airline industry. Moreover, it also contributes to protection and maintenance of historical places and parks. Local governments and other official bodies have focused their efforts on development of tourism industry to attract their target market (Kayumovich, 2020).

One of the reasons tourism has grown significantly over the past few decades is that people want recreation and entertainment during their vacations. Tourism demand is a need that stems from our desire to break the daily routine, get pleasure, relaxation and challenge (Robitashvili, 2018). There was a time in the past when tourism was only restricted to accommodation, transportation and entertainment sector where attraction for visitors were mostly theme parks, museums, amusement parks and historical places. Apart from the traditional concept of tourism, the event managers have tapped in the uncovered concept of event tourism, giving rise to event tourism industry. Local festivals act as an important tool for event tourism. In order to attract new tourists toward a region, festivals and events are planned, conducted and promoted. There are several reasons for the attractiveness and popularity of local festivals. For instance, festivals increase the demand of local tourism and create a positive image for the region. Festivals are highlighted in the development and marketing plans of most destinations, and play a significant role as a motivator for tourists (Getz, 2008).

In the tourism framework, economists have shown keen interest in examining financial impact of such festivals. It is observed that events and festivals play a key role in attracting visitors to host region, who otherwise would not usually travel to that country. Another positive economic effect is leveraging of events to develop local businesses (Chalip and Leyns, 2002). The popularity of festivals and special events has increased in recent years (Gursoy, Kim and Uysal, 2004). Festivals and events play an important role in tourism-related marketing (Camilleri, 2019). Tourism upholds a destination's image, and adds to the development and sustainability of the local economy. Therefore, it is in the best interest of those public, private, and non-profit organizations who wish to promote their city to support special events (Karabag et al., 2011). When conducting impact analysis of festivals from an economic perspective and for tourism development, standard proxies include measure of income and employment attributable to the festivals. Normally, the results are positive, and boost public support for the festivals (Felsenstein and Fleischer, 2003).

This study examined the influence of three significant factors, including firm's strategy, location, and type of business, on sales of local businesses during a festival. It considered Peace \& Love Festival as an example, which is the biggest music festival in Sweden. It attracts thousands of visitors every year from all over the world. Kamfjord (2011) described travelling and attending music festivals as themed holiday travel. It is based on attitudes and interests, which in this case primarily involves different kinds of music; rock, pop, or folk etc. 
NBR

3,1

Page 30

However, there are some other factors that are essential to the overall experience, such as the opportunity to experience music with others and feel the mood and sense of the community, contributing to an overall positive experience (Edström et al., 2003). The Peace \& Love Festival started in 1999 to reduce violence and racism in Borlänge \& Dalarna, and for giving a positive message of diversity, fellowship, understanding and humanity. Three men, Jesper Heed, Michael Krist and Henry Martokangas, were the founders of this Festival. They wanted to give a message of love and peace through this Festival. The Festival is much more than an ordinary music festival. The purpose of the Festival is to draw maximum number of visitors to Borlänge \& Dalarna, shaping their minds towards peace, humanity and love. The Festival has different themes every year, which gives the message in prominent ways. For example, in 2008, the theme was 'Wake Up', in 2009 'Passion', in 2010 'Freedom', in 2011 'Courage, hope and love' and for, 2012, the theme was 'A new world' (Peace and Love, 2012). In the year 2012, Peace \& Love Festival introduced two different kinds of festivals for the first time; Peace \& Love Film Festival and Peace and Love Strings. It is also worth mentioning that number of visitors in the Festival is increasing every passing year.

\section{Literature Review}

The tourism industry is currently one of the world's largest and fastest growing industries (Ranasinghe, 2016; Kapera, 2018; Kayumovich, 2020; Xudoyarov, 2019). Tourism is the temporary stay away from the normal place of residence, where the purpose of the visit is not to work, but to spend leisure time (Mathieson and Wall 1982). Tourism research involves studies on the tourists and their economic, social and physical impact on the host destination. It has major economic and social significance. It is estimated that approximately 270 million tourists spend US $\$ 92$ billion every year in places outside their home countries; being largest in the world's foreign trade. It is generating an influx of foreign currency in many countries. Both developed and developing countries have realized the importance of tourism, which can be seen from the efforts made by governments, sponsors, small businesses' involvement, multinational companies, and other concerned authorities (Mathieson and Wall, 1982).

The World Tourism Organization (2009) argues that the tourism industry has very strong links to economic development. In most of the developing countries, tourism is considered as a major source of income and generates new job opportunities in tourism-related sectors. Travel and tourism are a key feature behind economic and cultural development, and without travel, there will be no significant economic developments, cultural innovation or technological progress (Sahlberg, 2004).

Festivals and events primarily bring economic benefit to the local retail community (LCRA Community and Economic Development, 2011). They become a major reason to attract tourists, resulting in significant amount of spending by them. For instance, a tourist visiting a festival stays at local hotels, uses local modes of transportation, eats at local restaurants, fills up gas in the car, buys souvenirs, pays for parking, etc. Most grand festivals like Edinburgh (Scotland), and Glastonbury festival (England) generate economic benefits, increased opportunities of employment in the home country, and are much more than cultural events (Felsenstein \& Fleischer, 2003). 
NBR

3,1

Page 31

Even small festivals, for example, Carbondale Mountain Fair, Colorado, The Creole Christmas Festival, New Orleans, and the rock music festival in Loch Lomond, Scotland, generate positive financial impacts and create increased employment opportunities in the tourism destination. According to Felsenstein \& Fleischer (2003), more tourists get attracted to destinations which are rich in culture, have quality life, and hold festivals and events which are a great source of enjoyment. Therefore, a greater number of tourists means greater chances of increased revenues for local businesses (Felsenstein \& Fleischer, 2003; Laing, 2018).

Sales of any business can be enhanced by the right use of promotional techniques. Promotional techniques can vary from expensive, e.g. national advertising campaign for franchise chain, to inexpensive, e.g. flyers for take-out restaurants (Berman and Evans, 2001). Promotion plays a vital role in increasing sales, and therefore, businesses rely heavily on promotional activities to enhance their sales (Varley, 2006). Pricing strategies have many advantages, such as an increase in the profit of business, support for slow-selling merchandise, creation of excitement and attraction of customers, and reducing advertising / operating expenditures, etc. (Levy \& Weitz, 2012). An appropriate location is another vital element for a successful business. "You can be the best retailer in the world, but if you set up your shop in the wrong place, you'll never do much business. If you operate from the wrong properties, you start with your hands tied behind your back" (Clarke and Rowley, 1995). A good location is very significant for any business; a poor location can be a shortfall that is very difficult to overcome (McGoldrick, 2002). Location is important and interesting because location of any store is a controllable factor of business strategy, that can increase sales (Mishra, 2009). The sale of goods and services to the final consumer ranges from automobiles, to apparel, to movie theatre tickets (Berman and Evans, 2001).

\section{Methods}

Taking into consideration the limited resources in terms of time and costs, nonprobability based purposive sampling was drawn. In-depth face to face interviews were conducted with respondents. In order to contact the respondents, e-mail addresses and telephone numbers were gained through the internet. Thereafter, some respondents were contacted by sending formal invitation letters to get their permission for setting an agreed time for personal interview. Preferred time and place as per the respondents' convenience were set to ensure their ease. Although many respondents were contacted, 22 individuals from local businesses and the event management were eventually interviewed. During each interview, notes were taken. Each interview with an individual took around 30 minutes. Informed consent, anonymity and confidentiality concerns were addressed through standard protocol. The first part of the semi-structured questionnaire was designed to be answered by local businesses in Borlänge. It consisted of fourteen questions. The second part of the questionnaire was designed for the respondents representing Peace and Love Festival. This portion consisted of nineteen questions. The questions required basic information about Peace and Love Festival, the role that the Festival plays in promoting the local businesses, the response of the local community, how the Festival was marketed, number of yearly visitors, and such type of questions. During each interview, notes were taken. The collected data was documented and analysed using interpretivist and content analysis techniques. 
It was coded and entered. Of the 22 respondents, meaningful information was obtained from fifteen, while others provided limited answers.

\section{Results}

It has been analyzed from the literature review and the interview results that the three important factors of business strategy, location of business, and type of

NBR

3,1

Page 32 business, influence local businesses' sales during the Peace and Love Festival. It was also analyzed that the businesses can take maximum advantages of such events, and can maximize their overall return by going out of the way and making use of short term strategies. Most businesses, especially food businesses, have gone with short term expansion strategy. For instance, Clas Ohlson does not have any store in Borlänge, but in order to take advantage of Peace \& Love Festival and maximize their return during the event dates, they arrange for a tent inside the Festival area. Furthermore, we can consider examples of Coop Konsum and Burger King, which are also going with the expansion strategy and making their presence at such events to respond to the immense demand of the festival attendees. Expansion strategy has been taken up by businesses that have the ability to attain the marginal benefit greater than their cost, e.g., Burger King. Those who have not gone for expansion in terms of their existence in the Festival premises revealed plans to go for it by following successful businesses; one can refer to them as Market Followers, such as Ica Kvantum (Kotler \& Keller, 2006). Another fact analyzed from the interviews was that businesses usually do not tend to go for out-of-the-box marketing or advertising strategies as most respondents were of the view that these decisions are to be taken by the senior level management, and were of the opinion that advertising would be an added cost.

The Festival is the major reason for attracting tourists to Borlänge. The number of visitors to the Festival has steadily increased with every passing year, which is very good for the local businesses and the city from an economic perspective. When asked from the respondents, 'What do you think can have a positive impact on your sales?', one of the main factors was the increasing number of tourists which is resulting in increased sales and eventually maximizes earnings. The research showed the most positively affected businesses were hotels, fast food restaurants (Burger King, Max, and McDonald etc), pizzerias, etc., and businesses located near the Festival area. $100 \%$ respondents said that the main reason for increasing or decreasing sales trend is the location. The researcher found that the sale of Max restaurant increased during the festival week, but not like McDonald and Burger King, only because of location, as the latter chains had tents near the Festival premises; hence, they had increased sales, depicting the importance of location. The same was highlighted by all respondents. All respondents said that location is very important. This reflects the importance of one of the $4 \mathrm{Ps}^{\prime}$ of the marketing, i.e. Place. There are three keys to success "location, location, and location" (Kotler \& Keller, 2006, p. 516; McGoldrick, 2002, p.235). The electronic stores experience no impact on sales, and some stores even experience a decline in sales and lost their regular customers during the Festival week, such as stores like H\&M, Team Sportia, Skohuset etc. Coop Konsum was found advertising the store heavily, and it was also one of the major sponsors of the Festival. According to the respondent, this was their best week of the year in term of sales. It was found during the research that Coop Konsum uses different modes of advertisement. 
Peace \& Love Festival had advertised Borlänge on products such as Peace \& Love TShirt, on the information booklet about Peace \& Love, and banners which were placed everywhere inside and near the Festival areas. Promotional strategies play a

NBR

3,1

Page 33 fundamental role in raising sales, and many businesses rely heavily on promotional activities to enhance their sales (Varley, 2006, p.204). It is evaluated that the hotels had more than 100 percent sales during the Festival; they take early bookings months before the Festival, according to the interview with General Manager of one hotel. The researcher found that more jobs were created during the Festival as businesses need more manpower during this time, as for some businesses, this week is the year's best week in terms of sale. The study shows that businesses required more employees to fulfill the increased demand during the Festival time. Over $70 \%$ of the businesses required more manpower. Approximately 50 percent of the businesses increased their employees by more than 50 percent. Within them were few businesses that increased their manpower by more than 100 percent.

The Festival visitors also get to see the nature, beautiful landscape and other historical places of the city. They have a memorable experience which makes them want to visit again, and the image they take from here becomes a source of bringing new people to the city every year. Finally, the analysis from interview results showed that the Festival has significant power to attract a large number of visitors towards the host destination, and overall, it has a positive effect from a financial point of view. Results shows an increase in sales of different businesses during the Festival week. Around $8 \%$ businesses did not experience any increase in their sales. There were also a few businesses that had a decline in their sales due to the type of business they had. All the remaining businesses found an increase in their sales. Sales of some businesses doubled. There were also some businesses whose sales increased but they were reluctant in sharing the percentage of increase. It has been analyzed that the three important factors discussed influenced the sale of local business during Peace \& Love Festival. Last but not least, it has been analyzed that by adopting and implementing different strategies such as expansion, price cutting, strategies for market challenger (intensive advertising strategy), etc., businesses can maximize their profits and take advantage of the Festival.

\section{Findings}

The researcher found the businesses that implemented different strategies generated more revenue as compared to those who did not have any strategy. All the retail stores saw about 10 to $30 \%$ increase in sales, but Coop Konsum is the only retail store that has quadrupled (almost 400 percent) sales during the Festival because of good strategic implementations as well as location. Coop Konsum places one stall of fast food outside the area near parking, and one inside the Festival area. They implemented different marketing strategies; they had sponsorship with Peace \& Love Festival, and they also promoted themselves through heavy advertising. The promotional activities included advertising, sales promotion and personal selling. Sales of any business can be increased by the right use of promotional techniques (Berman \& Evans, 2001). Promotion plays a vital role in increasing sales, and businesses rely on promotional activities to enhance their sales (Varley, 2006, p.204). The researcher found that some businesses had discount offers for customers, such as special coupons from Peace \& Love Festivals. However, majority of businesses did not conduct any marketing efforts to promote their businesses during the Festival (reason was already high sales of these businesses). 
NBR

3,1

Page 34

Almost none of the businesses made any changes in the prices of products during the Festival. During the research, it was found that the hotels increased the rent of rooms during the Festival because of increased demand, resulting in full occupancy in hotels; hence, customers were willing to pay more. Previous experiences showed that businesses do not have an idea as to how much products they would be able to sell, so their counters were emptied quickly as supply of their products was too low compared to the demand. With time, they learnt how to deal with the issue. Most businesses extended the opening hours during the Festival week in order to increase the sales, but some did not extend the opening hours. All the businesses in Kupolen could extend their opening hours as they had to follow the opening hours of Kupolen. It was observed that those businesses which were involved in conducting marketing activities were using very traditional methods, such as advertising through billboards, television, newspapers and radio. They were also offering discount offers and introducing some new products. However, there were many businesses having no strategic plans. Companies with no strategic plans were already satisfied with their increased sales. Hotels were having early booking months before the Festival time.

Location is one of the most important elements for any business in order to increase their sales during festivals. The same is depicted through literature review and interview findings. Interview guide contained a question "Does location matter, and how much for your business?" All respondents said that location of business affects their sales as it is the most important element during the Festival. Those businesses which were located nearer to or inside the Festival area experienced higher sales in comparison to those which are located afar. As already highlighted in the literature review, for any business to be successful, there are three keys; "location, location, and location" (Kotler \& Keller, 2006, p. 516, McGoldrick, 2002, p.235). For instance, during the Festival, the sale of McDonald's was much more than the sales of Burger King and Max, only because of its lucrative location. Likewise, the sale of Ica Kvantum was more than the sale of Ica Maxi, reason being an attractive location.

During the research, it was observed that all the hotels, beverage companies and fast-food restaurants witnessed an increase in their sales during the Peace \& Love Festival week. Retail stores like Lidle, Öob, Ica Maxi, Ica Kvantum etc. experienced almost 10 to 30 percent increase in sales. The sales percentage showed variations depending on the type of business. For instance, the electronics and appliance stores showed little or no increase in sales, such as M Store's sales decreased during the Festival week, and the electronics and appliance store like Kjell \& Company had a slight increase in sale. The researcher found that one of the reasons for low sales was the declining number of their regular customers during the Festival week. The shoe stores also saw very little increase in sales; clothing stores like H\&M, Jack \& Jones also had limited increase in sales.

\section{Recommendations}

Majority of businesses are not having any marketing plans for generating or improving their sales during the Festival week. This might be one of the reasons for those businesses that were unable to take advantage of the Festival. Hence, it is suggested that such businesses need to have strategic plans for future events, including advertising plans and promotional strategies. This would help businesses to brand their organizations and products, and attract more visitors. 
NBR

3,1

Page 35

In order to increase the sales during the festivals, business can introduce promotional and corporate gifts for their customers; these promotional gifts can be in the form of coupons or discounts on different products and attractive festival offers that can help to develop business. The corporate gifts can include promotional items like diaries, pens, handmade gifts, clocks, etc. Some businesses experienced shortage to supply as they were not able to forecast demand. Hence, to meet demand, effective management is required. As noted, businesses located nearer to the Festival area generated more sales. Hence, it is suggested that those which were located further away from the Festival area can have stalls near the area in order to gain more revenue during Festival week. They can increase their sales further if they are successful in occupying counters inside the Festival area.

It is suggested that other businesses can also increase sales if they have some kind of sponsorship with the Festival. Also, it is observed that Coop Konsum had advertisements almost everywhere that improved its sales further. It is also recommended that businesses can extend their opening hours to take maximum advantage of the event. It is also observed that some businesses gained more sales as compared to others depending on the type of businesses. Hence, it is suggested that those businesses which are more relevant to the needs of visitors should come up with strategic plans to take advantage of such events.

\section{Research Limitations}

Limitations appeared while conducting interviews, e.g., it was difficult to coordinate with the concerned individuals for interview scheduling as they were very committed. Moreover, few respondents were reluctant to give interview as they were of the opinion that information provided can be used against them by their competitors. Furthermore, respondents were having a very busy schedule, therefore, they were unable to spare more time for interview. The average time for each interview was 25 to 35 minutes. Respondents were unwilling to give interview on audio recording; hence, the information provided was documented by taking written notes. They also showed apprehension to provide exact figures of sales, and thus shared approximate values.

\section{Conclusion}

The results of research interviews reflect that if the number of tourists increases, sales might also increase. Peace \& Love management is adopting different strategies that can increase the number of tourists, like bringing more international artists and more promotion for Peace and Love Festival. It is concluded from the study that Peace \& Love Festival has positive effect from a financial viewpoint on local businesses and travel and tourism industry. Around $70 \%$ of the businesses confirmed that they experienced increased sales due to the Festival. One finding from the study is that different types of business experienced varied sales during the Festival, and this was obvious from the fact that hotel businesses benefitted from the Festival and earned more profits. On the other hand, electronics businesses had reverse scenario e.g. department store Elgiganten lost even their regular customers during the Festival week. Another strong observation was that location of a business from the Festival is very important for the success of business during the Festival. An example to support this fact was the statement from owner of Burger king, who said "As compared to McDonald, we have lower sale only because of location". 
NBR

3,1

Page 36

All respondents supported the fact that location is one of the most important elements that affect sales during the Festival week. Hence, it has been concluded that those businesses which were nearer to the Festival area generated more sales as compared to those which were afar.

In terms of strategic implementation, the researcher concluded that the hotels, all fast-food restaurants and beverages gained higher revenue compared to other sectors. The retail stores showed slight increase in revenue while electronic stores had almost no change, and some even had negative revenue. From the location perspective, the businesses (restaurants, retailer store, and other business) nearer to the Festival area are generating more revenues. It is also concluded that the businesses who implemented effective strategies generated more sales from Peace \& Love Festival compared to those who did not make any strategies. However, it has been observed that majority of businesses were not taking advantage of marketing strategies as they were not having any marketing plans. As a result of this study, it has been concluded that all three factors discussed in the article influence sales of local businesses during the Peace and Love Festival. It has also been concluded that by adopting different strategies, businesses can take maximum advantages of events and enhance their revenue. It is pertinent to mention that events such as Peace \& Love Festival are important instruments to generate huge sales for local businesses, to help in the development of travel \& tourism industry, and the host destination Borlänge and Dalarna County.

\section{References}

Berman, B. \& Evans, J.R. (2001). Retail Management a strategic approach. Eighth edition, New Jersey, Prentice Hall Inc.

Chalip, L. \& Leyns, A. (2002). 'Local business leveraging of a sport event: managing an event for economic benefit', Journal of Sport Management, vol. 16, pp. 132158.

Clarke, I. and Rowley, J. (1995). A case for spatial decision-support systems in retail location planning. International Journal of Retail \& Distribution Management, Vol. 23, Issue 3, pp. 4-10.

Edström et al. (2003), Evenemangsföretagande, Studentlitteratur, Lund.

Etchner, C.M. \& Brent Ritchie, J.R., (1993). The measurement of destination image: an empirical assessment. Journal of Travel Research, 31 (3) pp.3-13.

Felsenstein, D. \& Fleischer, A. (2003). Local Festivals and Tourism Promotion: The Role of Public Assistance and Visitor Expenditure. Journal of Travel Research 2003 41: 385,

Getz, D. (2008). Event tourism: definition, evolution and research. Tourism Management,29, pp. 403-428.

Gursoy, D., Kim, K., and Uysal, M., 2004. Perceived impacts of festivals and special events by organizers: an extension and validation. Tourism Management vol. 25, 171-181

Kamfjord, G. (2011). Det helhetlige reiselivsproduktet. Oslo: Fagspesialisten

Karabag et al. (2011). The impact of festivals on city promotion: A comparative study of Turkish and Swedish festivals.

Kotler, P \& Keller K. (2009), “Marketing Management" 1st European ed. Italy: Person Education limited. 
NBR

3,1

Page 37

Levy, M. \& Weitz, B.A. (2012). Retailing Management. Eighth Edition, New York, McGraw hill international.

Mathieson, A. \& Wall,G. (1982). Tourism economic, physical and social impacts. New York, Longman

McGoldrick, P.J. (2002). Retail Marketing. Second Edition, Berkshire, McGraw hill education.

Mishra, S., 2009, GIS in Indian Industry- A strategic tool. International Journal of Marketing Studies, Vol.1, issue 1, pp 50-57.

Ranasinghe, R. (2016). Potentials of Chinese outbound travel for the growing tourism industry of Sri Lanka; A review. World Wide Journal of Multidisciplinary Research and Development, 2(1), 66-69.

Sahlberg, Bengt, (2004), Rötter, riter och roller - Turism och resande i upplevelsesamhället, ETOUR/SNS Förlag, Östersund.

Varley, R. (2006). Retail Product Management. New York: Routledge

Xudoyarov, A. A. (2019). The role of visiting tourism in the peculiarities and aspects of the tourism industry in the global markets. American Journal of Economics and Business Management, 2(4), 180-190.

Kayumovich, K. O. (2020). Prospects of digital tourism development. Economics, (1 (44)).

Kapera, I. (2018). Sustainable tourism development efforts by local governments in Poland. Sustainable cities and society, 40, 581-588.

Robitashvili, N. (2018). Tourism Statistics in Georgia. International Journal of Innovative Technologies in Economy, 2(6 (18)), 51-53.

Laing, J. (2018). Festival and event tourism research: Current and future perspectives. Tourism management perspectives, 25, 165-168.

Camilleri, M. A. (Ed.). (2019). Tourism planning and destination marketing. Bingley: Emerald Publishing.

\begin{abstract}
About Authors
Sobia Shujaat: Ms. Sobia Shujaat is working as Assistant Professor in Business Studies Department at Bahria University Islamabad, Pakistan. She has numerous national and international publications in areas of marketing, consumer behaviour and human resource management. The author has more than 200 citations to her research articles.

Dr Iram Tahir (*Corresponding Author) Dr. Iram Tahir has 14 years of teaching and research experience with universities in Pakistan and UK. She is a qualitative research consultant and a human resource development specialist. She is Member Editorial Board, Global Management Journal for Academic and Corporate Studies, and an International Reviewer for PhD Theses, Department of Public Administration, University of Karachi. She also coaches and mentor young professionals in personal and professional development aspects. Owais Tahir: A practicing project manager with a Project Management Professional (PMP) certification, keynote speaker, and an academician teaching the discipline of project management at SZABIST University Islamabad, through effective communication skills and a deep understanding of the project management knowledge. His research interests include risk management, organizational change, and project documentation and framework for project success
\end{abstract}


